\title{
Viewpoint: The importance of range science to federal graz- ing policy
}

\author{
BRIAN CZECH
}

Author is graduate research associate and Ph.D. candidate, School of Renewable Natural Resources, University of Arizona, Tucson, Ariz 85719.

\begin{abstract}
The value of science to policy design is questioned by many, including political scientists. Critics view scientific expertise as subject to monopolization by an elite technocracy; a process with antidemocratic consequences. Science has been influential in the development of federal grazing policy by creating the Clementsian paradigm, by affecting the policy agenda, and by defining terms of discussion. Science has been less influential in the implementation of grazing policy. In contrast with many policy issues, science is important to sound grazing policy, because western rangelands are isolated from the thought process of the general public by geographic, demographic, and temporal features. In America, good policy is that which solves important problems and fosters democracy. Democratic forums in which grazing policies are born are enlightened by the disciplined competency of science. More than any other form of knowing, science represents concentrated, devoted study of a topic. Range science should provide the basis of public information and opinion that is converted, via the political process, into federal grazing policy.
\end{abstract}

Key Words: expertise, history, technocracy

In the policy arena, science is a two-edged sword. It can help to slice through the pluralism that has long reduced public policy to the perpetual "muddling through" that Lindblom aptly described (1959) and documented periodically since $(1979,1988)$. Scientific management has been extolled at least since the Progressive movement that ushered in the 20th century (Knott and Miller 1987). Science has transcended its application to management, however, and has carved out a large niche in public policy itself (Quade 1982, Brewer and deLeon 1983). At its worst, science can excise much of the public participation by which democracy is served (Dryzek 1990).

Once widely viewed as a panacea for policy problems, the scientific perspective is increasingly viewed as the problem itself, creating a communication gap between the policy arena and the public, and a dependence of policy makers on technical expertise rather than public preference (Fischer 1990). The German sociologist, Max Weber, predicted as much while observing the Progressive buildup a century ago, and even foresaw a sub-

\footnotetext{
Author would like to thank Dr. Helen Ingram for her motivation, ideas, and review.

Manuscript accepted 11 Aug. 1996.
}

servience of politicians to scientists (Weber 1978). Of the dependence of policy makers on technical experts, Barnes and Edge (1982:233) said, "It is hard to exaggerate the practical importance of this problem. It pervades whole areas of policy... the list is endless." If that were strictly true, then grazing policy would be included. My viewpoint addresses 2 questions: 1) In the arena of federal grazing policy, how well entrenched is range science? 2) Is the scientific perspective helpful or harmful in the design of grazing policy?

To answer the first question, I will employ a scheme recently developed by Schneider and Ingram (in press). Schneider and Ingram envisioned the amount of scientific influence on policy design to fall along a spectrum from "no influence" to "complete control of all phases of design".

The second question is impossible to answer without specifying the evaluation criteria. American public policy should solve problems in an efficient manner while fostering democracy (Ingram and Smith 1993). (Democracy is "...a means of selecting policy makers and of organizing government to ensure that policy represents and responds to the public's preferences [Lineberry 1980:33].") A phenomenon, the scientific perspective in this case, should be defined as "helpful" in the formulation and implementation of policy when it contributes to both of these ends, or at least to one without hindering the other. In other words, the impact of range science on grazing policy will not be evaluated from a purely scientific perspective, because such an evaluation would be guilty of begging the question. Heeding the civic-minded exhortations of Ingram and Smith (1993), the merits of range science will be evaluated in more holistic terms.

\section{Historical Overview of Range Science}

Arthur W. Sampson (1923) wrote the first range management textbook, and established the Clementsian view of plant succession as the ecological paradigm of the range management profession. In this view (Clements 1916), vegetation is seen in terms of community stability, with disturbance (e.g., grazing) causing an interruption in a community's succession to its naturally stabilized, or "climax", state. When Dyksterhuis (1949) published a paper detailing the use of the climax concept in evaluating the condition and trend of rangelands, it "resulted in the institutionalization of the concept as national policy for dealing with rangeland resources" (Johnson and Mayeux 1992:323). Although Clementsian succession may have been abandoned by increasing numbers of plant ecologists during the post Dust Bowl decades, "All major inventory and classification methods in use today are 
modifications of that basic [Clementsian] concept" (National Research Council 1994:61).

The Clementsian paradigm was early and frequently challenged by plant ecologists, beginning with the individualistic concept of plant associations (Gleason 1926). Criticisms center around the lack of evidence for ecosystem stability, the evidence for "natural" plant invasions, and stochastic processes in the organization of plant communities (Johnson and Mayeux 1992). Due to the policy implications, the argument has intensified in recent years. The Clementsian paradigm encourages range reformists to rail against the conversion of plant communities by overgrazing, while critics argue that nature would do the same thing, if on a different time scale.

\section{The Influence of Range Science in Grazing Policy}

The amount of influence that range science has held over grazing policy is a bit paradoxical. Apparently regardless of which theory is in vogue, range scientist Herman Mayeux believes that,"The accepted theory of vegetation dynamics and ecosystem function strongly influences public policy and law in essentially all matters concerning our environment, and the efficacy of such policy and law depends on whether or not the theory is a [sic] fundamentally sound" (Johnson and Mayeux 1992; 323). Yet, political scientists have usually attributed the design of grazing policy to pluralistic politics (e.g., Foss 1960, Clarke and McCool 1996), and forest and range policy specialists Cubbage et al. (1993) consider the Bureau of Land Management (BLM) to be a textbook example of agency capture.

Perhaps these observers are considering different portions of the aforementioned policy influence spectrum, rather than the entire spectrum. In preparing their manuscript, Schneider and Ingram (in press) scored the amount of influence that science has on a policy as 2 if it contributes to the formulation of policy alternatives, 4 if it modifies policy specifications during implementation, 6 if it provides the underlying rationale for policy design and implementation, 8 if it defines the issues and related terminology, and 10 if it completely controls the policy arena.

Under this scheme, range science should be given credit for about 5 or 6 total points. This is not quite the same as saying that the position of range science on the spectrum is 5 or 6 . $^{1}$ Considering the elements separately, surely range science gets 2 points for contributing to the formulation of policy alternatives, and for providing underlying rationale (especially the Clementsian paradigm) for policy design and implementation. Range science has to some extent defined the issues (e.g., value of native vs. exotic species), too. On the other hand, due to agency capture, it has not been historically dominant in the implementation of policy on BLM lands, and has been quite powerless in the political contests of the policy arena (Foss 1960, Cawley 1993).

By comparison, scientific expertise has been credited with far more influence in other natural resource policy arenas. Perhaps the best example is endangered species policy. The Endangered Species Act of 1973 (16 U.S.C. 1531-1544) has been called "...one of the most sweeping pieces of prohibitive policy to be

\footnotetext{
${ }^{1}$ Schneider and Ingram recognized the difficulty of portraying scientific influence along a spectrum. They have replaced it with a table in which each element of influence is considered separately (A. Schneider, Arizona State Univ., pers. comm., 12 July 1996), as I have done.
}

enacted..." (Yaffee 1982:13), and wildlife scientists are clearly responsible for much of its origins, rationale, and implementation. By some accounts, the scientific expertise involved in endangered species management would score a 10 in the Schneider and Ingram system; Mann and Plummer (1995:220) thought the Endangered Species Act "...ended up turning... wildlife biologists into ecological mandarins, deciding the fate of resentful communities."

Even in policy arenas where scientific expertise is thought to be exceedingly powerful, however, critics are wary of moving too far in the other direction. They tend to acknowledge that expertise is required for sound decision making, and that purely politicized policies are no better than technocratically derived ones. Thus, continuing their discussion on the role of wildlife biologists in endangered species policy formulation, Mann and Plummer (1995:229) added, "...[Noah's] ark is not big enough, and no one is better equipped to decide which species, communities, and ecosystems are more necessary than others and how best to protect them."

\section{Worth of a Scientific Perspective to Grazing Policy Design}

Fischer (1990), Willard (1990), and Schneider and Ingram (in press), have outlined in generic terms the problems caused by a deference to scientific expertise in the design of policy. These problems include an unhealthy cessation of policy dialogue in the public sphere, potential for fallacious argumentum ad verecundiam (appeal to authority), public cynicism, and an undemocratic dependence of policy makers on technical expertise rather than public preference. As the above discussion suggests, however, and as Schneider and Ingram (in press) emphasize, each policy arena must be assessed within its socio-political context. Grazing policy stands out immediately for several reasons.

First, federal grazing policy is concerned with the activities on the public rangelands of 11 western states, while federal policy makers are accountable to a constituency with a majority residing in the East. Second, ranching is a rural occupation, while the overwhelming majority of citizens are urbanites. Third, the effects of grazing are to be measured in terms of ecological and geological time, while human society tends to operate on circadian, or, at the longest, corporate time. Each of these distinctions point to a greater-than-average importance of sound range science in policy design.

Recall that science is useful to policy when it solves problems in an efficient manner, as long as it does not hinder democracy. I propose 2 components to problem-solving capability on the western range; experience and education. It is highly unlikely that an easterner, or even a western urbanite, will have any range experience, and practically all citizens are isolated from the type of decision making that applies to geological time. The general public's problem-solving potential, then, is contingent upon education. Good candidates for providing that educition are those that study the topic full time and are relatively accessible; i.e., range scientists and natural resource scientists in general.

Given that range science contributes to problem-solving capacity in the design of policy, does it then pass the test of promoting (or at least failing to hinder) democracy? A major criticism of technocracy is that it does not (Dryzek 1990. Fischer 1990). In the case of federal grazing policy, however, the same factors that 
enhance the worth of range science for problem solving do likewise for democracy.

Eastern and urban citizens are not eliminated from discursive democracy by range scientists. Policy makers, rather, have set the tone for the level of public participation in grazing policy debates. In a string of legislation that began with the National Environmental Policy Act (42 U.S.C. 4341-4347) and stretched to the Federal Land Policy and Management Act of 1976 (43 U.S.C. 1701-1784), Congress was explicit that there be planning efforts for the management of public natural resources, and that these efforts would formally incorporate public participation. For that reason, the Stockmen Advisory Boards that were created by the Taylor Grazing Act of 1934 (48 Stat. 1275) and were comprised entirely of ranchers, have been replaced by interdisciplinary committees that include interested citizens. In addition, BLM management plans are subject to public review periods which include the assembling of public hearings by the BLM. Congress has not been entirely unsuccessful in fostering democracy with these policy revisions.

What role does range science play in these public forums? As Fischer (1990) pessimistically points out, the scientific nature of a topic dissuades many citizens from entering the discourse. These citizens may feel inhibited by the intellectual and authoritative nature of such proceedings. What Fischer neglects to mention, however, is that citizens who do participate ask difficult, intelligent questions, and experts are often the only ones capable of postulating an answer. The loss of citizen participation caused by a scientific presence in the public forum is countered by the tendency of scientific expertise to turn a potentially incoherent argument into a more informed debate.

\section{Conclusion}

The role of science in policy design has been critically reviewed in recent times by political scientists, who focus on the pitfalls to democracy caused by the authority of expertise. Sometimes these criticisms neglect the other aspects of sound policy, but as Schneider and Ingram (in press) point out, good policy not only fosters democracy but solves important problems.

In the case of federal grazing policy, it appears that science has been relatively influential by creating the Clementsian paradigm, affecting the agenda, and defining terms, and less influential in terms of implementation. Range science should be credited with but a subset of this influence, however. Plant ecologists, wildlife biologists, foresters, and other natural resource scientists have contributed a large proportion of "range" science.

Science is a valuable component of sound grazing policy, because western rangelands are isolated from the thought process of the general citizenry by powerful geographic, demographic, and temporal features. The "ideal speech situation" of liberal democracy includes not only unconstrained discourse, but competency also (Habermas 1970). Some argue that science may not be the best form of knowing, in terms of policy formulation. More than any other form, however, science represents concentrated, devoted study of a topic. It is therefore the logical candidate to inform that considerable portion of the public that is interested in federal grazing policy.

\section{Literature Cited}

Barnes, B. and D. Edge. 1982. Science as expertise. Pages 233-249 in B. Barnes and D. Edge, eds. Readings in the sociology of science. Mass. Institute of Technology Press, Cambridge, Mass.

Brewer, G.D. and P. deLeon. 1983. The foundations of policy analysis. Dorsey Press, Homewood, Ill.

Cawley, R.M. 1993. Federal land, western anger: the Sagebrush Rebellion and environmental politics. Univ. Kan. Press, Lawrence, Kan.

Clarke, J.N. and D. McCool. 1996. 2nd ed. Staking out the terrain: power and performance among natural resource agencies. State Univ. of N.Y. Press, Albany, N.Y.

Clements, F.E. 1916. Plant succession: an analysis of the development of vegetation. Carnegie Inst. Pub. 242. Washington, D.C.

Cubbage, F.W., J. O'Laughlin, and C.S. Bullock III. 1993. Forest resource policy. John Wiley \& Sons, Inc., New York, N.Y.

Dryzek, J.S. 1990. Discursive democracy: politics, policy, and political science. Cambridge Univ. Press, Cambridge, U.K.

Dyksterhuis, E.J. 1949. Condition and management of rangeland based on quantitative ecology. J. Range Manage. 2:104-115.

Fischer, F. 1990. Technocracy and the politics of expertise. Sage Publications, Newbury Park, Calif.

Foss, P.O. 1960. Politics and grass. Univ. Wash. Press, Seattle, Wash.

Gleason, H.A. 1926. The individualistic concept of the plant association. Torrey Bot. Club Bull. 53:7-26.

Habermas, J. 1970. Towards a theory of communicative competence. Inquiry 13:360-375.

Ingram, H. and S.R. Smith, eds. 1993. Public policy for democracy. The Brookings Institution, Washington, D.C.

Johnson, H.B. and H.S. Mayeux. 1992. Viewpoint: a view on species additions and deletions and the balance of nature. J. Range Manage. 45:322-333.

Knott, J.H. and G.J. Miller. 1987. Reforming bureaucracy. PrenticeHall,Englewood Cliffs, N.J.

Lindblom, C.E. 1959. The science of muddling through. Public Administration Review 19:79-88.

Lindblom, C.E. 1979. Still muddling, not yet through. Public Administration Review 39:517-526.

Lindblom, C.E. 1988. Democracy and market systems. Norwegian Univ. Press, Oslo.

Lineberry, R.L. 1980. Government in America: people, politics, and policy. Little, Brown and Co., Boston, Mass.

Mann, C.C. and M.L. Plummer. 1995. Noah's choice: the future of endangered species. Alfred A. Knopf, New York, N.Y.

National Research Council. 1994. Rangeland health: new methods to classify, inventory, and monitor rangelands. National Academy Press, Washington, D.C.

Quade, E.S. 1982. Analysis for public decisions. Elsevier Science Publishing Co., Inc., New York, N.Y.

Sampson, A.W. 1923. Range and pasture management. John Wiley and Sons, London, U.K.

Schneider, A. and H. Ingram. In press. Policy design for democratic governance. Univ. Kan. Press, Lawrence, Kan.

Yaffee, S.L. 1982. Prohibitive policy: implementing the federal Endangered Species Act. Mass. Institute of Tech. Press, Cambridge, Mass.

Weber, M. 1978. Economy and Society. Univ. Calif. Press, Berkeley, Calif.

Willard, C.A. 1990. Authority. Informal logic 12.1:11-22. 